\title{
Environment and human health: a threat to all
}

\author{
Rajendra Ramlogan \\ University of Cambridge, UK
}

Focuses on the direct and indirect impact of environmental abuse on human wellbeing. In some instances, the impact of environmental abuse on human health is not still unknown, merely being subject to scientific suspicion. This would suggest caution and the need for preventive measures to be applied. The threat to human health from environmental factors is not an isolated problem that exists on a national level. There are environmental factors that affect human health on a global level or are so widespread as to be considered global problems. Other environmental problems cross national boundaries and achieve regional importance.

Environmental Management and Health

8/ 2 [1997] 51-66

(c) MCB University Press

[ISSN 0956-6163]

\section{Introduction}

The world that we inhabit has been shaped largely by acts of nature and of man. The subject of the shaping of the environment by natural forces and its effect on man does not form part of this review. Instead this paper is dedicated solely to an analysis of the role of man in the abuse of the environment and the extent to which this affects human health and well being. There is a long litany of man's mi suse of his environment, and evidence shows that the situation has worsened dramatically over thelast 300 years. The conflict appears to have intensified, creating concer $n$ that we may be pushing ourselves to the brink of a global disaster. Factors such as the Industrial Revolution of the mid-ei ghteenth century, which started in Britain and made its way to Europe and Nor th America, and the insatiable appetite for fuel, and the great technological strides that accompanied the Industrial Revolution, urbanization, the commercialization of agriculture, the rise in consumerism, and population growth, have often been heralded as the turning point for the moder $n$ crisis that has arisen between man and the environment. Yet despite the early start to environmental problems, it is perhaps true that as the twenti eth century prepares to give way to the twenty-first, the full scale of the health implications of environmental degradation has started to be revealed.

Good heal th has been one of the major goals of humankind throughout the march of history. The World Health Organizati on (WHO) defines health as the state of complete physical, mental and social well being of man; not merely freedom from di sease or infirmity (Weisner, 1992, p. 1). It has been argued that the basi c requi rements for an acceptable level of health are a suitable di et, decent shelter, companionship, an adequate income and a heal thy environment. Importantly, good heal th requires a constructive balance between individuals or groups and the environment (Weisner, 1992, pp. 2-4). It is being recognized that the physical environment is the most important deter minant of good health and, consequently, protection of the environment and preservation of ecosystems are fundamental in the struggle against human illnesses (Cortese, 1993, pp. 1-3). Existing evidence suggests that the most serious potential consequence of global environmental change is the decimation of the Earth's life-support systems (M cMi chael, 1993, p. xiii). Cor tese has asserted that rapid industrial growth, the population explosion, resource depletion, alteration of the chemical composition of the atmosphere and the cycling of carbon, nitrogen and phosphorous are factors largely responsible for altering the basic physiology of the Earth (Cortese, 1993, p. 2; Godlee and Walker, 1992, pp. 1-8). In the words of M cM ichael (1993), it would appear "that this fabric of life-supporting mechanisms is now starting to unravel, in a brief geological moment, as the cumulative global i mpact of human activity escalates" (p. 5)".

One of the increasingly apparent features of life in the latter half of the twenti eth century is the growing inter dependency of the global village. This trend towards a smaller, more accessible and inter related world has justifiably led to many different areas of concern, one of which pertains to the environment. Developing a uniform definition of what is meant by the term "envi ronment" has proved elusive. For purposes of this paper, a working definition of the environment shall refer to:

- the physical el ements of the Earth, namely the air, water, land surface, sub-surface strata (together with all living resources therein);

- outer space;

- ambient background and human habitations;

- the workplace;

- indigenous peoples; and

- the natural, cultural and common heritage of the world.

While there may be many consequences of environmental degradation in the global community, one of the emerging principal concerns lies in the area of human health. This paper is dedicated to the review of existing scientific investigations so as to develop a greater understanding of how environmental factors can impact not only on national and regional communities, but also on the international community and adversely affect the 
Rajendra Ramlogan

Environment and human

health: a threat to all

Environmental Management and Health

8/ 2 [1997] 51-66 aspirations of human society for a better future. Thus, as the conflict between man and the envi ronment intensifies, it would be wise to bear in mind that the human body may pay the ulti mate price for the indiscretions of the human race.

Environmental degradation and human health: the global village

\section{Global warming}

Climate change is destined to affect the entire global village as it is a planetary occurrence. A war mer world is forecast as a result of the effects of greenhouse emissions. It is now thought that human health may be affected by global warming. Under warmer conditions, heat stress related conditions may become more common, leading to increases in morbi dity and mortality (Longstreth, 1990, p. 525; Schneider, 1989, p. 182). Warmer summers may produce higher infant and foetal mortality due to summer time increases in infections (Longstreth, 1990, p. 525). Moister and warmer conditions would facilitate the nor thward spread of insect-bor ne diseases, for example, from mosquitoes and ticks (Schnei der, 1989, p. 182). One possi ble di sease that may flourish under conditions of gl obal warming is malaria. Addi tionally, warmer and moister conditions may lead to higher rates of skin infecti ons (Longstreth, 1990, p. 525).

Depletion of the stratospheric ozone layer Another environmental problem with global consequences is the depletion of the stratospheric ozone layer, and here human health may very well prove to be the most direct casual ty. Exposure to ultravi olet-B radiation can cause a suppression in immune systems leading to an increase in infections (Morison, 1992, p. 49). A dditionally, there may even be a possible decrease in the effectiveness of vaccines (UNEP, 1990, p. 116). Skin pigmentation would not protect against deficiencies in the immune system, so rendering persons in the tropics equally at risk (Ilyas, 1989; J eevan and Kripke, 1993, p. 1160).

Enhanced levels of ultravi olet-B radiation can lead to increased damage to the eyes, leading to a higher inci dence of cataracts. Cataracts can impair vision and even cause blindness. It has been estimated that the incidence of cataracts would increase by 0.6 per cent per 1 per cent ozone depletion. This may result in an additional 100,000 cases of blindness worldwide (UNEP, 1990, p. 116). With respect to other ocular ailments, it is antici pated that there would be a rise in cases of kerato-conjunctivitis or snow blindness.
Finally, long-ter $m$ increases in ultraviolet-B ir radiance will enhance the risk of nonmelanoma skin cancer (Madronich and De Grujl, 1994, pp. 541-6). It is projected that every 1 per cent decrease in the total ozone column will result in a 3 per cent rise in the incidence of non-melanoma cancer (Diffey, 1992, pp. 2267-79; UNEP, 1990, p. 116). Cases of the more dangerous malignant melanoma are also antici pated (Henriksen et al., 1990, pp. 579-82; J ones, 1989, p. 213). Ultraviolet-B radiation can increase mortality and morbidity significantly through mel anoma and nonmelanoma skin cancers. On a less serious level to skin cancer, ultraviolet-B radiation can also result in acute erythema or sunburn, a condition that will especially afflict light skinned people (J ones, 1989, p. 208). The effect of ozone depletion would be to shift populations closer to equatorial conditions of ultraviolet exposure than genetically per missible (J ones, 1989, p. 215). Developing countries with al ready underdevel oped health-care systems would suffer tremendously if there is an upsurge in infection rates or cataract formation (Tolba and El-Kholy, 1993, p. 34).

\section{Marine resource}

The threat to the oceans by pollution is capable of creating havoc throughout the world. Pollution of oceans origi nates from many sources. Today over 60 per cent of the world's population live within the vicinity of a coastline, with two-thirds of the world's cities with populations of more than $2.5 \mathrm{milli}$ on situated near estuaries (Tol ba and El-Kholy, 1993, p. 107). This high level of population in the vicinity of oceans has led to the direct dumping of municipal wastes at sea, where very often liquid and semi-solid wastes are simply pumped through short pi pes (White, 1993, p. 87). A dditionally, man's use of the oceans has led to pollution from within the ocean. It is esti mated that approximately 6.4 million tons of general shi pboard litter are dumped annually by ships at sea (Tolba and EI-Kholy, 1993, p. 120). Further, ocean users mainly involved in the fishing industry gener ate 136,000 tons of plastic, nets, lines and buoys and 22,000 tons of plastic contai ners, all of which contribute to littering of the ocean (White, 1993, p. 85).

Hydrocarbon pollution is one of the best known sources of ocean contamination. Yet surprisingly, spectacular oil tanker spillages contri bute a mere 22 per cent to the hydrocarbon pollution of oceans. An overwhel ming 59 per cent comes from the routine flushing of oil tanker holds. Radi oactive waste is also a contri butor to pollution of oceans as these ecosystems were consider ed dumps of last resort. In some instances solid municipal waste and even hazar dous waste are si mply 
Rajendra Ramlogan

Environment and human

health: a threat to all

Environmental Management and Health

8/ 2 [1997] 51-66 transported out into the sea and dumped. In recent times, hazardous waste was transported to sea and incinerated. A shes and other contaminants that are not effectively neutralized by incineration are dumped at sea (White, 1993, pp. 86-7). Finally, offshore mining activities have contributed to the pollution of the oceans. In Thailand it has been discovered that offshore tin mining has degraded sea water quali ty and damaged reef ecosystems (Ruyabhorn and Phantumvanit, 1988, p. 229).

By far the greatest health threat from pollution of the world's oceans comes from fish contamination. The United Nations Environmental Programme (UNEP) has estimated that over 20 billion tons of waste including sewage, agricultural run-off and industrial waste are dumped into the ocean annually. A pproximately 90 per cent remain near coastlines which, together with reefs provide around 95 per cent of the world's fish catch (Tolba and El-Kholy, 1993, p. 117; White, 1993, p. 87). Fish contamination can have serious health implications. The consumption of contaminated seafood can lead to serious health problems, particularly in developing countries where, as noted before, the oceans provide the major source of protein. The Minimata mercury poisoning incident in J apan is an example of the adverse consequences of consuming contaminated seafood (White, 1993, pp. 85-6). In Minimata mercury waste produced by a local industry was poured into the sea to enter the human food chain through contami nated seafood. The result was the onset of debilitating human illnesses associated with mercury poi soning.

\section{Chemicals}

There are cer tain areas of environmental degradation that al though taking place within national boundaries are so widespread as to justify global concern. One such area is chemical pollution. From time immemorial, man has engaged in the manufacture of chemicals. These products are used on our bodies, in our homes, fields, food, transport and indeed in almost every aspect of our life. It has been calculated that between 1956 and 1982, over 4 million distinct chemical compounds were formulated with as many as 6,000 new for mulations being created weekly since. Wilson (1993) states that approximately 3,000 chemicals are deliberately added to food, 700 have been found in drinking water, about 400 have been identified in human tissues and over 500 could be found under the kitchen sink or in the laundry room of the average house. The fact that over 70,000 chemicals are in dai ly use creates a cause for concer $n$ especially with regard to issues of health and safety (p. 1).
Pesticides are probably the most wi despread and infamous source of chemi cal contamination which exists in the atmosphere, water, soil and food. The world woke up to the horrors of the indiscriminate use of pesticides with the publication of the famous Silent Spring by Rachel Carson (1991). The wi despread use of pesticides is a feature of the twenti eth century, the manifestation of another tool to assert control over nature. The rise of pesticides is inti mately linked with the discovery in 1939 of the insecticidal capabilities of dichloro-diphenyl-trichloroethane (DDT) (M cE wen and Stephenson, 1979 pp. 2-4). From that point onwards pesticides have played an important role in human society. They have been used for a myriad causes, such as the controlling of pests, enhancement of crops, destruction of diseasecausing insects and improvement of household condi tions by eradicating those living organisms that have led to di scomfort in dwelling places (McE wen and Stephenson, 1979, pp. 8-19).

The adverse effects of chemicals on human heal th is by far the most important area of concern. Chemical contamination can enter the organs of living things through air, water and food. Simple inhalation of contaminated air can induce adverse reactions in the human body. Food is an important source of chemical contamination that facilitates the ingress of har mful chemicals into living things. Contaminants can be acquired at the production, harvesting, processing, packaging, transport, storage, cooking and serving stages. The application of pestici des and preservatives contaminates food because of the persistence of chemi cal resi dues. Normal level s of airbor ne chemi cal contaminants can contribute to contamination of food but the result may not necessarily be acute toxicity. Water can contami nate food in several ways. Consumption of fish and shellfish containing chemical contaminants provides a pathway for chemicals to enter into the human body. Consumption of vegetable products that may have been cultivated with contaminated ir rigated water is another significant pathway. Even the consumption of livestock which may have drunk contaminated water is a possi ble conduit for the transfer of chemical contamination (Lippmann and Schlesinger, 1979, pp. 24-7). Additionally, the drinking of chemically tainted water is also a predi ctable way of becoming exposed to the har mful effects of chemicals ( $M$ cE wen and Stephenson, 1979, pp. 280-1). Finally, consumption of crops grown on chemi cally tainted soils represents another possible entry point for chemical contami nants into the human body. 
Rajendra Ramlogan

Environment and human

health: a threat to all

Environmental Management and Health

8/ 2 [1997] 51-66
In the majority of cases exposure is via inhalati on but it can al so result from exposure of the skin (Lippmann and Schlesinger, 1979, p. 51). The respiratory tract is the main point of entry into humans for airbor ne chemicals. Chemicals which are water borne or transported in food reach man through the gastrointestinal tract. These can also be absorbed into the human body through the skin. The range of biological responses to chemical contaminants in the body is quite diverse and may range from irritant, fibrotic, asphyxiant, allergic to carcinogenic (Lippmann and Schlesinger, 1979, pp. 194-214). It has been estimated that three out of every ten people in the USA can expect to contract some for $m$ of cancer, and in approximately 98 per cent of the cases these may belinked to chemical exposure. In addition to cancer, chemical exposure is responsible for a myriad other health problems ranging from neurological, immunological and developmental to reproduction (Wilson, 1993, pp. 2-4). Wilson provides one of the most comprehensive treatises on the health implications of various chemicals. The list of hundreds of likely ailments from chemical exposure is a chilling reminder of human vulnerability (Wilson, 1993, pp. 11-72). Without doubt, exposure to har mful chemicals can increase mor tali ty and morbidity (Blain, 1990). Most cases of wi despread mortality are the result of industrial accidents and spillage of chemicals as occurred in Bhopal, in India. However, although deaths have occurred through less spectacular media, there are much fewer data available in cases where the exposure may have been a long-ter $m$ probl em (Lippmann and Schlesinger, 1979, pp. 53-4).

The occupational environment is another major source of exposure to har mful chemicals among humans and merits special mention. It has been asserted that most cases of chemical poisoning have arisen from occupational exposure. More than ever, chemical production is shifting to devel oping countries where the regulatory framework is less severe than in developed countries. The result has been a rise in cases of chemical poisoning although there is significant underreporting and lack of research in this area. Various studies, however, have led to reasonable estimates of the magnitude of the problem. In Tai wan it was discovered that employees in a plant engaged in the manufacture of pestici des had substantially decreased plasma cholinester ase (Wu, 1989, pp. 661-3). Not only those who manufacture the pestici des are affected but workers who are engaged in administering the chemicals are equally, if not more, at risk. A study in India revealed a prevalence of respi ratory ai Iments among sprayers in mango plantations. The sprayers, because of an absence of proper safety equipment, were directly exposed to the pesti cides through skin contact and respiration and indirectly through food consumption (Rastogi , 1989). The problem of improper protection of workers using pesticides has given rise to what has been described as an epidemic of pesticide poisoning in Nicaragua (McConnell and Hruska, 1993).

The examples noted above in the case of workers dealing with har mful chemi cals are not isolated but indicative of a much broader problem and pesticide poisoning has emerged as a major concer $n$. WHO and UNEP have estimated that over one million cases of pestici de poi soning occur yearly, with around 20,000 fatali ties (Pimentel et al., 1992, p. 750). A more recent study has suggested that the incidents of pestici de poi soning may beas high as three million annually (McConnell and Hruska, 1993, p. 1559). In spite of the developed countries using around 80 per cent of the pesticides produced in the world, it has been estimated that 99 per cent of pesticide fataliti es occur in the developing world, with just as significant a percentage in the area of non-fatal poisonings. A nother area of concer $n$ in the developing world is the high level of perinatal mortality. It has been estimated that there are about seven million perinatal deaths per annum in developing countries. A study in Sudan has indi cated a consistent and statistically significant relationship between exposure to pesticides and the increased risk of still birth or perinatal death (Taha and Gray, 1993, pp. 319-20).

\section{Nuclear operations}

Nuclear operations are national activities with global implications. The biggest fear pertaining to nucl ear activities arises from the possibility of the use of nuclear technology as a weapon and nuclear acci dents. The ter restrial envi ronment can become affected by radi onuclides emitted or discharged either accidentally or deliberately from a series of pathways. There can be direct deposition of contaminated soils by flooding or ir rigation with contami nated water, or aerial wet or dry deposition. Accordingly, ter restrial vegetation may become contami nated as a result of direct deposition or radionuclides entering from the soil (Pentreath, 1980, p. 173). Some emissi ons like i odine-131 after deposition on foliage can be directly ingested from affected fruits and vegetation or through the cowmilk-man pathway (Pentreath, 1980, pp. 146-7). Thus, man may be affected by radioactive emissions through consumption of fruits and vegetation, cow's mi lk or meat from animals that may have consumed contami nated vegetation (Pentreath, 1980, pp. 180-1). The discharge of liquid effluents in the aquatic 
Rajendra Ramlogan Environment and human health: a threat to all Environmental Management and Health

8/ 2 [1997] 51-66 envir ronment can also find its way into the human body either by drinking affected water or consumption of fish and other aquatic sources of human food that may have been contami nated (Pentreath, 1980, pp. 158-65).

A dangerous threat to human health arising from the use of nuclear technology is the possi bility of exposure to radiation. Injury to living organisms arises from damage to cells in the body. High levels of radiation lead to both somatic and genetic changes in living organisms. Somatic effects are those resulting di rectly from the radiation dose received by the affected cells and manifest themselves in some for $m$ of radiation-induced malignancy (Eichholz, 1977, p. 121). The effects include increased inci dence of leukaemia and other types of cancer, including tumours of the thyroi d gland, lung, and the breast in women. Higher incidence of bone cancer has also been observed in some instances (Glasstone and J ordan, 1980, pp. 184-91). Genetic effects arise when the reproductive cells are ir radiated, resulting in changes in the genes or chromosomes of these cells, and the subsequent handing down of these changes to descendants of the affected individual. There are different types of geneti c changes, namely, gene mutati ons, chromosome aber rations, and changes in the number of chromosomes. These changes can result in the presence of abnormalities in offspring ranging from lethal to mildly detrimental (Eichholz, 1977, p. 123).

Environmental degradation and human health: the regional connection

\section{Freshwater}

Water is the essence of life, without which man's existence can be transfor med into one continuous liturgy of suffering. This is currently evident in places like the Sahel region. However, in addition to water availability, water quality also poses a problem, particularly in developing countries. It may be accurate to state that the need for a safe domestic water supply is perhaps the greatest threat to the devel oping world (Witt, 1982, p. 301). Where water supply is low and water treatment inefficient, human heal th is at its most vulnerable point (Feachem, 1983). The concer $n$ in many developing countries focuses on a supply of safe and adequate amounts of water for consumption and sanitary purposes. The United Nations Development Programme (UNDP) has esti mated that during the period 1988-1991, 70 per cent of the devel oping world had access to safe water, with the figure dropping to 45 per cent for the least developed countries. With respect to sanitation facilities, 56 per cent had access with a mere 32 per cent for the least devel oped countries (UNDP, 1994, Table 2, p. 132). These figures translated in 1992 to approximately 1.3 billion people without access to safe water and 1.9 billion without access to proper sanitation facilities (UNDP, 1994, Table 3, p. 135).

The heal th implications flowing from the failure to supply water of sufficient quality for domestic usage are tremendous in developing countries. In addition to the direct threats that may flow from consumption of water contaminated by pollutants such as chemi cal agents, the greatest cause of mortality and morbidity is the spread of infectious diseases. In the devel oping world these account for 72 per cent of the deaths of all children under five years old and 45 per cent of deaths over all. The prevalence of infecti ous di seases is di rectly attri butable to malnutrition, inadequate water supply, lack of sanitation facilities, poor hygienic practices and unsatisfactory living conditions (UNEP, 1993, p. 235).

There are five major pathways for waterrelated diseases to betransmitted to humans. First, there are water-bor ne diseases which can arise from multiple causes, such as the presence of human or animal faeces in water, urine infected by bacteria and pathogenic viruses. These organisms are transmitted to humans when the water is used for drinking or food preparation (UNEP, 1993, p. 235).

Examples of water-bor ne diseases are poliomyelitis, ascariasis, enteric fever and diarrhoeal diseases. In the late 1980s there were approximately three billion cases of these di seases, primarily in the developing world with over 4.07 million fatalities, with diarrhoeal diseases such as cholera and typhoid accounting for four milli on deaths (UNEP, 1993, Table 5.6, p. 256).

Water-washed diseases are caused by the scarcity of water, which renders cleanliness difficult to attain. This category includes all water-bor ne diseases in addition to infestation with lice or mites which are vectors of typhus (Nash, 1993, p. 26). Common types of water-washed afflictions are trachoma and leishmaniasis. In the late 1980s these conditions affected up to 21 million people in the developing world and in the case of trachoma rendered between si $x$ and nine million people blind (UNEP, 1993, Table 5.6, p. 256).

Water-based diseases are those in which water provides the habi tat for the immediate host organisms in which certain parasites pass part of their life cycle (Nash, 1993, p. 26). The host organism may be ingested during consumption of fish or other freshwater food or the drinking of infected water. Examples of water-based conditions are schistosomiasis and dracunculiasis which affected around 
Rajendra Ramlogan

Environment and human

health: a threat to all

Environmental Management and Health

8/ 2 [1997] 51-66
$210 \mathrm{million}$ people in the developing world in the late 1980s. During this period, schistosomiasis resulted in approximately 200, 000 fatalities (UNEP, 1993, Table 5.6, p. 256).

Water-related diseases are those in which insect vectors of parasitic diseases rely on water as a habitat. In this case transmission is not due to direct human contact with water (UNEP, 1993, p. 235). A frican trypanosomiasis, el ephantiasi s, onchocerciasis, yellow fever, dengue fever, J apanese encephalitis and malaria dominate this area accounting for $435.04 \mathrm{mi}$ Ilion cases in the devel oping world in the 1980s wi th fatalities ranging between one and 2.05 million. Malaria accounted for the bulk of the cases with 267 million and between one and two million of the recorded deaths (UNEP, 1993, Table 5.6, p. 256).

Finally, there are water-di spersed infections where the infecti ous agents thrive in fresh water and are inhaled into the respiratory tract with minute water droplets. Legi onella is an example of a water-di spersed infection and this category of water-related diseases is the only one that appears with some frequency in devel oped countries (UNEP, 1993, p. 235).

The startling statistics of water-based diseases recited above are perhaps the tragic proof that the greatest threat to developing countries lies in obtaining a fresh water supply for domestic usage. Without urgent attention to this requirement, the lives of billions may be si mply wasted away.

\section{Desertification}

One of the alarming features of the last two decades has been the growing desertification of several regions in the developing world, the most noticeable being the Sub-Saharan region. While the loss of biological diversity and human suffering are the most apparent manifestations of deser tification, there may even behealth consequences. Crop failure and loss of livestock often leads to malnutrition. Weakened bodies are then rendered susceptible to the ravages of hunger and disease. Although few diseases are specific to desertificati on, eye disease such as trachoma and other afflictions like bil harzia may be more prominent under condi tions of desertification (Secretariat of the United Nations Conference on Desertification, 1977, p. 42).

Environmental degradation and human health: national risk

Indoor air pollution

There are areas of environmental abuse that giverise predominantly to national health problems. One such area is indoor air pollution which has ravaged the developing world with an estimated 400 to 700 million people being at risk and annual deaths to infants and children of around four million annually (World Bank, 1992, p. 52). The major problems are caused by non-biomass and bi omass combustion. Non-biomass indoor combustion nor mally pertains to the use of gas ranges for cooking. Generally, indoor gas ranges do not have a gas exhaust system, so allowing the gaseous products of combustion to enter the indoor air directly during use (Greim, 1989, p. 193). The two major emissions are carbon monoxide and nitrogen dioxide.

Carbon monoxide is emitted as a result of the incomplete combustion of carbonaceous material. In addition to gas ranges, water heaters and gas or coal heaters are major indoor sources of carbon monoxide. Carbon monoxide produces toxic effects in the human body. Due to its affinity to haemoglobin it displaces oxygen, so lowering the oxygen carrying capacity of blood. Carbon monoxide has its most toxic acute effects on the organs with high oxygen requirements, such as the heart and the brain. At low levels, carbon monoxide can cause flu-like symptoms especially in children (Gold, 1992, pp. 216-7). A t high levels, it can lead to coma and possibly death (Wellburn, 1988, p. 17). Nitrogen dioxide is an oxidant that is solublein tissues. Most inhaled nitrogen dioxide is retained in the lungs and deposited primarily in the large and small airways. At high concentrations nitrogen di oxi de causes extensive lung injuries. Fatal pulmonary oedema and bronchopneumonia have been reported at high concentrations, with bronchitis and pneumonia at lower levels (L ambert and Samet, 1994, p. 612).

Biomass fuels comprise processed biomass such as charcoal, methane, logging waste and sawdust. Unprocessed bi omass fuels are generated from sources such as wood, dung, straw, agricultural wastes and vegetable matter. Burning of biomass for fuel can result in the production of particulates, benzo(a)pyrene, carbon monoxide, nitrogen dioxide, sulphur dioxide, formaldehyde, volatile organic compounds and numerous other substances (Gold, 1992, p. 218). In this area the developing world appears most vulnerable. Unfor tunately, except for the work of Chen (1990), the issue has not been comprehensively researched in the devel oping world.

It has been stated that indoor pollutants may pose a greater health risk in the devel oping world than outdoor air pollution due to the fact that many people, especially women, spend a lot of time indoors (Davidson, 1986, p. 561). Biomass supplies 14 per cent of the world's primary energy, with the developing world accounting for approximately $35 \mathrm{per}$ cent of that figure. In some devel oping 
Rajendra Ramlogan Environment and human health: a threat to all Environmental Management and Health

$8 / 2$ [1997] 51-66 countries, biomass accounts for as much as 90 per cent of the primary energy. Approximately 50 per cent of the world's population predominantly from the devel oping world, rely mainly or exclusively on bi omass fuels to satisfy their daily energy needs, that is, for cooking and heating (UNEP, 1993, p. 273).

In devel oping countries, it has been shown that the incidence of lung cancer rises as a result of exposure to particulates and gaseous emission arising from burning of biomass fuel in what are often poorly ventilated houses. Additionally, there is a higher incidence of chronic bronchitis in non-smoking women, and respi ratory ailments and pneumonia among children (Gold, 1992, p. 218). These trends have been borne out in the increasing number of case studies perfor med in developing countries, particularly in Africa and Asia. Exposure to gaseous emi ssions from bi omass burning has been linked with diminished lung functions in children in Kuala Lumpur, Malaysia (Azizi and Henry, 1990, p. 26). In a case control study performed in the province of Guangzhou, China, lung cancer emerged as the major cause of death by cancer among men and women. Smoking appeared to be dominant among male fatali ties but with respect to women could not have been a significant factor, because of lower smoking activities. Theresults of the study indicated that indoor air pollution due to home cooking was the driving factor in lung cancer among women who were exposed to coal fumes and cooking oil vapours (Liu et al., 1993). In Shenyang, China, a case control study of 1,249 patients with lung cancer found that while cigarette smoking was a major contributory factor, indoor air pollution was the significant factor in the case of women. The risk of lung cancer was between 50 to 70 per cent higher in homes heated by coals or using coals for cooking. Where kang was used for heating bedrooms or cooking was done within close proximity of sleeping quarters, the risk was at its highest level (Xu, 1989). In Shanghai, the indoor burning of coal has been positively linked to a higher incidence of stroke among males (Zhang, 1988, p. 976).

The grim picture in A sia extends to A frica where similar results were obtained. In Zimbabwe, investigations have revealed that children are morelikely to suffer from pneumonia in homes where wood is used as fuel (Lancet, 1992, p. 397). In rural Kenya, measurements of indoor air pollution revealed that respirable particulates and nitrogen oxide were approximately ten times higher than the recommended air quality guidelines. Additionally, the level of polycyclic aromatic hydrocarbons was al so quite high (Boleij et al., 1989, p. 1677). A study in Ghana has noted the adverse health effects on women and young children arising from the burning of biomass fuel for cooking. A plethora of respiratory problems bears witness to the tragedy of indoor air pollution (McGranahan and Songsore, 1994, pp. 4-45).

Pandey et al. (1989) have noted that, in the developing world, the exposure to high levels of smoke from indoor bi omass burning without a flue or chimney and with poor ventilation is responsible for acute respi ratory infections that cause one-third of all childhood deaths under five years. Further, the basic evidence suggests that peak and daily exposures to indoor particulate levels would appear at times to be 20 times greater in the developing world than the developed (Pandey et al., 1989, p. 427). One study has revealed that in selected developing countries, the average annual micrograms of pollutant is 300 per cubic metre of air in rural areas, with the cor responding figure for the developed world being 75 per cubic metre of air (Smith, 1988, p. 19).

\section{Outdoor air pollution}

Outdoor air pollution is another serious environmental factor that can impact adversely on human health. Although it is dealt with as a national problem, it can quite easi ly pose transboundary problems, especially in areas of concentrated air pollution, such as the Black Triangle in Europe between Ger many, Poland and the Czech Republic. Indeed, it is arguable that outdoor air pollution among nations with common boundaries is so widespread as to justify its consideration as an area of global concer $n$. There are many for ms of outdoor air pollution and this paper will focus on just a few examples. One common type of outdoor air pollutant is refer red to as suspended particulate matter (SPM). SPM refers to the wide range of finely divided solids or liqui ds dispersed into the atmosphere from natural sources, industrial activities and combustion processes. The composition of SPM s varies but typically includes carbon, higher hydrocarbons for med by incomplete combustion of hydrocarbon fuels, and sulphur, the latter of which may account for up to approxi mately 20 per cent of the total SPM s (Elsom, 1992, p. 21). Thus, the effects of SPM $s$ on the environment are highly influenced by sulphur-based emissi ons. The health impact of such levels of emissions is tremendous and exposure to SPMs has been linked with higher incidence of asthma, bronchitis and pulmonary emphysema (EIsom, 1992, p. 27).

A nother common type of air pollutant is sulphur dioxide. This is a colourless gas emitted from sources similar to SPM s. Its emission is highest from the combustion of coal and oil. Sulphur dioxide reacts catalytically 
Rajendra Ramlogan

Environment and human

health: a threat to all

Environmental Management and Health

8/ 2 [1997] 51-66 or photochemically with other pollutants to form sulphur trioxide, sulphuric acid and sulphates (EIsom, 1992, p. 22). Sulphur is historically regarded as one of the traditional sources of pollution. At its zenith, sulphur pollution has manifested itself in the famous sulphurous smogs that afflicted most industrial cities. Smogs are generally for med when meteor ol ogi cal conditions fail to disperse large quantities of pollutants emitted from industry, vehicles and domestic sources. Sulphur-related products can have a fatal impact on human health as evidenced by the infamous sul phurous smog that struck London in December 1952. The death of nearly 4, 000 people was the result wi th the largest contributor being bronchitis, foll owed by other diseases characterized by impair ment of respiratory functions (EIsom, 1992, pp. 22-5). On a less fatal basis, sulphur dioxide produces a strong irritation on the eyes and the nasal passageway. Moreover, sulphur di oxide emissions have been linked with higher incidences of asthma, bronchitis, pulmonary emphysema and a general reduction of lung functions especially in children (Well burn, 1988, pp. 53-6). A nother particular variation of sulphur emissions is hydrogen sulphide. It is slightly phototoxic and at high levels it can irritate the lung passage and eyes of humans possibly resulting in pneumonia and conjunctivitis (Well burn, 1988, pp. 182-6).

Oxides of nitrogen arealso dangerous sources of air pollution. The principal anthropogenic emissions of oxides of nitrogen are from the combustion of fossil fuels in fixed sources like power plants and heating, and in motor cars from the internal combustion engine. In developed countries, the operation of power plants contributes approximately 45 per cent of the emission of oxides of nitrogen, road transport about 30 per cent, with the balance from domestic and general industrial sources (Well burn, 1988, p. 68). The health implications of emissi on of oxides of nitrogen may not be as powerful as other air pollutants but ought not to be under esti mated. Nitrogen dioxide is known for its stinging, suffocating odour. Fur ther, evidence points to increased airway resistance and sensitivity to bronchoconstrictors in certain individuals (Elsom, 1992, p. 49). At high levels of exposure, nitrous fumes may cause coughing, headaches and chest tightness. This may lead to sudden circulatory collapse and water accumulation in the lungs. Excess blood nitrate may reduce blood pressure which in turn could cause destruction of blood cells, liver and kidney defects (Wellburn, 1988, p. 91).

Photochemical oxidants also contribute to the danger ous cocktail of air pollutants that are present today. Evaporation of solvents and fuels together with the incomplete combustion of fossil fuels causes various hydrocarbons to be released into the atmosphere (Wellburn, 1988, p. 135). Photochemical oxidants are secondary pollutants for med by the action of sunlight on an atmosphere containing reactive hydrocar bons and oxi des of nitrogen. These reactions produce many oxi dants with peroxyacetyl ni trate and ozone being the most significant. The key to the formation of ozone is the photolysis of the nitrogen dioxide molecule by ultravi olet radiation during daylight hours. Photochemical oxidants in their smoglike for $m$ are capable of causing eye and nose irritation. During epi sodes in Los A ngeles in September 1979, 55 per cent of the people surveyed complained of burning or irritation of the eyes, 25 per cent reported headaches, breathing irritation, sore throats or stuffy noses, whi le hospitals recorded almost a 50 per cent admittance rate increase for complaints of l ung di seases such as emphysema and asthma (Elsom, 1992, pp. 40-43). Studi es have revealed that exposure to ozone can cause increased ai rway resistance and decreased ventilatory perfor mance (Fishman and Kalish, 1990, p. 233). Moreover, it would appear that ozone may injure the bronchiolar and alveolar walls of the lungs (Fishman and Kalish, 1990, pp. 215-6).

$\mathrm{N}$ ot to be outdone as a key contributor to outdoor air pollution is carbon monoxide. Carbon monoxide is a colourless, odourless gas produced by the incomplete combustion of carbon-containing fuels. Carbon monoxide is also emitted from biological and industrial processes, the burning of forests and waste matter products, and the activities of industrial installations such as petroleum refineries, steel mills and power stations. However, the major source of carbon monoxide emissi ons is the exhaust of petrol-powered motor vehicles. In contrast, properly adjusted di esel engines emi t very little carbon monoxide (Elsom, 1992, p. 51). The health impact of carbon monoxide has al ready been noted in the discussion on indoor air pollution.

Finally, outdoor air pollution is also influenced by the presence of trace elements. Toxic metals found in the atmosphere due to anthropogenic emissions can pose serious threats to human health. M ost of the toxic elements are more dangerous close to the particular source of emission and to the labour force working in the particular installation generating the toxic elements. The major trace elements are lead, cadmi um, chromium, manganese, mercury, nickel, vanadi um, aluminium, arsenic, copper, selenium and beryllium. This section will focus on the three most dangerous trace el ements, lead, mercury and cadmi um. Lead is the most dangerous toxic el ement and is different from 
Rajendra Ramlogan

Environment and human

health: a threat to all

Environmental M anagement and Health

8/ 2 [1997] 51-66 other toxic elements in that it is employed extensively by soci ety. The major sources of lead arise from its industrial and technological usage. The dominant source is in its use as an anti-knock additive in fuel. Lead is also produced in the making of batteries, sheet and pi pe, cable sheathing, solder, shot and paint (EIsom, 1992, p. 55). The inhalation of lead into the body combined with its deposi tion from other sources creates a significant health risk. Theingestion of lead causes acutelead poi soning characterized by burning abdominal pains, coma and heart failure. At lower levels, clinical symptoms include tiredness, aching of the joints, anaemia and abdominal colic (Davies, 1987, p. 4). At the lower level s of lead ingestion, a special concer $n$ has arisen with respect to children. It would appear that a low level of lead in the bodies of children can cause subtle neurological damage without any apparent signs of lead encephalopathy (EIsom, 1992, p. 58). The result appears to be a lower intelligent quotient level for affected children.

Cadmi um is a trace element that is widely dispersed in the atmosphere. Anthropogenic emissions are primarily due to mining, smelting, fossil fuel combustion and metal processing industries (Nordberg, 1992a, p. xi). All industrial processes involving zinc also have some connecti on wi th cadmi um. In humans, cadmi um intake can cause lung damage, gastrointestinal disorders, kidney damage and bone disease. Some studies have suggested that cadmi um is also carcinogenic but this is still not yet proved (Nordberg, 1992b, pp. 7-9). Mercury is another trace element that is fairly common in the atmosphere. Its anthropogenic sources include steel plants, power plants, battery factories, ore smelters, ceramic and cement factories. Exposure to mercury may lead to significant damage to human health (Semu and Singh, 1986, pp. 1416). Mercury poisoning can cause death in humans or at lower level s symptoms akin to lead poisoning.

\section{Hazardous waste}

Hazardous waste is also essentially an area of national concer $n$, but capable of el i citing global concer $n$. The onset of industrialization has led to the production of many different types of hazardous waste. The growth in the production of hazardous waste has coincided with growing limits on the capacity of industrialized nations to dispose of these undesi $r$ able by-products. The result has been the development of a transboundary trade of hazardous waste and increasing gl obal concer $n$. The biggest risk associated with hazardous waste is its improper disposal. Not only landfill gases, but many hazardous materials are carcinogenic or neurotoxic, and people who work at these disposal sites or those who scavenge for a living may be at serious risk. The food chain would also be endangered as careless di sposal of hazardous waste contaminates flor a and fauna. Not only may sensitive species die but humans may become infected by consuming contaminated food products (Donald, 1992, pp. 422-3).

A mong A frican countries, the potential for envi ronmental harm is greater because of the high usage of water from untreated natural sources and the heavy reliance on natural products (Logan, 1991, p. 65). Leaching of hazardous waste into the water stream or disposal near sea sites may be hazardous to marinelife, especially fish, and cause damage to other aspects of the aquatic ecosystem. Estuaries or river deltas are popular sites for industry in developing countries as many population centres are si tuated at such points. Estuaries are important areas for conservation as well as routes for migratory fishes and fish production (Petts and Eduljee, 1994, p. 163). Contamination of these critical areas of aquatic bi ological diversity can lead to adverse effects such as reduction in the sea food harvest which in turn can lead to debilitating effects on the economy of many developing countries.

The developing world has shown a great willingness to import hazar dous wastes, yet would appear to betotally unprepared for participation in the nefarious activities masquerading as inter national trade. UNEP has identified some of the problems facing developing countries in the disposal of hazardous wastes. These are poor pollution control, lack of financial resources, low level of public awareness, lack of staff with technical and managerial skills, lack of infrastructure for management and control, and the general absence of data on the generation, transport and disposal of hazardous wastes (Biswas, 1989, p. 265; Donald, 1992, p. 423; UNEP, 1993, pp. 329-39). A study of the hazardous waste trade in the Caribbean Basin has noted the absence of the technol ogical knowledge either to dispose of imported hazardous waste safely or to process or reduce it to an innocuous end product. Further, the study revealed the non-exi stence of the necessary equipment or expertise to detect escape from the medi um of containment used for hazardous waste. It was noted that the level of medical equi pment and exper tise to diagnose and treat ailments related to hazar dous waste disposal were invariably absent (Suite, 1991, p. 223).

Non-hazardous waste

Non-hazardous waste, although in appearance more benign than hazardous waste, can prove to be a significant threat if not dealt 
Rajendra Ramlogan Environment and human health: a threat to all Environmental Management and Health

8/ 2 [1997] 51-66 with properly. The WHO has stated that uncollected refuse poses a serious threat in developing countries as it is a major factor in the spread of gastrointestinal and parasitic diseases, mainly as a result of the proliferation of insect and rodent vectors (UNEP, 1993, p. 331). The British Medical Association has observed that poor maintenance of sewers, food waste and tipping can lead to increased cases of leptospi rosis (British Medical Association, 1991, p. 27). Additionally, dumping of municipal wastes at sites near squatters or urban settlements can lead to increased risk of poisoning and other heal th hazards to near by occupants, including those who scavenge at dump sites (UNEP, 1993, p. 331).

Sewage sludge is also a potential area of concer $n$. Sewage sludge has generally been defined as a slurry of organic rich particles. This sludge has a variable chemical content depending on its source and the efficiency of the treatment process. Sewage sludge can be used as fertilizers or processed into compost (UNEP, 1993, p. 339). The problem is that in many developing countries the treatment of sewage is inefficient and the waste stream is often mixed with other forms of hazardous wastes. This could lead to contamination of lands where the sludge is applied or groundwater into which it is discharged. The dangers of contami nati on of water systems and land with sewage are compounded by the fact that over 1.9 billion people in the developing world do not have access to sanitati on facilities (UNDP, 1994, Table 3, p. 135). This results in dumping of raw sewage in trash heaps, public land areas or water courses (Rei chard, 1990, p. 13). A gain, the dumping of raw sewage can giverise to a host of di seases that may adver sely affect the health of man (World Bank, 1992, p. 54). Crops may also become contaminated and consumption by humans may prove fatal. Additionally, human consumption of animals that have eaten contaminated fodder can provide a pathway into the body.

Noise pollution

Noise pollution is not an invention of moder $n$ man. Milne (1979) has noted that J ulius Caesar was so annoyed by the repetitive thud of horse hooves and the sound of speeding wheels, that he attempted to ban dayti me chariot racing (p. 16). However, noise pollution is certainly becoming one of the less desirable features of today's world. The major sources of noi se are generally heavy machinery at work complexes, transport vehicles, home appliances and lei sure activities such as music (Kryter, 1985, p. 167). Transport mechanisms are by far the greatest producers of adverse noise levels. From motor vehicle traffic in urban centres, the individual is generally subjected to high noise levels (Milne, 1979, pp. 23-33). Similarly, the effect of noise from aircraft around the vi cinity of air ports is an area of grave concern. Industrial noise or noise that emanates from manufacturing complexes is of concer $n$ not only for thoseliving in the area where the noise is being produced, but al so to the empl oyees who are exposed to even greater levels over consistent periods of time (Milne, 1979, pp. 34 40).

The effects of noise pollution on man are manifested as both auditory and non-auditory symptoms. On the auditory level, noise pollution can lead to loss or diminution of hearing ability. This is even more profound at places of work with high noise levels. Noise can damage or destroy the mi croscopic hair cells that transmit sound from the ear to the brain, leading to both temporary or permanent damage (Faruqui, 1985, p. 189). Temporary damage occurs if there is a non-per manent shift in the hearing threshold due to noise exposure. Where there is repeated exposure to the high noise levels over a long period of time as in a factory, there is a gradual deterioration in the organ of Corti resulting in a per manent shift of the hearing threshold (Cunniff, 1977, pp. 101-2). It has been clearly shown that peopl e such as the Mabaan tribe of Sudan who live in quiet communities possess far greater hearing abilities than people inhabiting the industrialized world (Faruqui, 1985, p. 189).

The non-auditory impact of noise pollution is varied. Noise produces peri pheral vasoconstriction which can result in reduced blood volume and blood flow to certain parts of the body with an increased blood flow to the head. Noise can also lead to changes in blood pressure, heart rate, cardiac output and pulse volume. One study among factory workers in noisy environments in the Federal Republic of Ger many showed a higher suscepti bility to cardiovascular di sease than among workers in less noisy environments ( $F$ aruqui, 1985, p. 190). Noise can create both neur ol ogical and psychological effects on the central nervous system. One study in London revealed a higher rate of mental illness among people living in noisy neighbourhoods. Noi se may affect al so man's vision and sense of balance. It has been demonstrated that noise can cause dizziness and impair one's ability to select relevant from irrel evant visual infor mation (Faruqui, 1985, p. 190). High noise levels can lead also to sleep interfer ence. There are different stages of sleep ranging from drowsiness to deep slumber. Noise polluti on may interfere with the sleep patter $n$ of an individual resulting in the deprivation of the restorative process for organs to renew their supply of energy and nutritive elements. The loss of 
Rajendra Ramlogan

Environment and human

health: a threat to all

Environmental Management and Health

8/ 2 [1997] 51-66 sleep affects one's personal well being and may i mpact negatively on activities such as job performance (Cunniff, 1977, p. 111; Shapiro, 1993, p. 75). Speech interference also occurs because of high noise levels as it can become a source of frustration or lead to distortions in the development of the speech level of an individual. It is al so one of the human consequences of envi ronmental noise pollution that is considered when noi se regulations are being framed (Cunniff, 1977, p. 109). Finally, high noi se levels create stress and can lead to the development of feel ings of annoyance, frustration, intolerance and moodiness (Shapiro, 1993, p. 75). This level of stress may impact adversely on the psychological wellbeing of an individual (Cunniff, 1977, pp. 111-3).

Light pollution

One of the new and emerging areas of environmental harm relates to light pollution, and medical research has uncovered a potential medical effect on humans due to light pollution. It has been argued that artificial light should be consi dered as an important component of carcinogenesis (Kerenyi et al., 1990, p. 76). The effect of light is felt mainly through the pineal gland. It is generally accepted that melatonin, the most significant pineal hor mone, produces a non-specific oncostati c effect. The synthesization of melatonin takes place in darkness with production diminishing in light. With the rise of artificial lighting, there has been a drastic increase in daily exposure to light. As a result, the production time for melatonin from the pineal has been severely reduced. This reduction has consequently decreased the oncostatic effects of melatonin, leading to significant increases in the incidence of tumours, particularly among the younger age group (Kerenyi et al., 1990, pp. 76-7). It has also been argued that light pollution can affect one's sl eeping ability leading to increased stress (Neale, 1995, p. 4).

Environmental degradation and human health: the unknown factor

\section{Acid rain}

In some areas of environmental degradation, the human health risk factor is not fully understood, but is nevertheless of grave concern. One such area is acid rain which is capable of affecting entire regions. The effect of acid rain on human health has been coming under increased scientific scrutiny. So far acid rain has not been shown to have any direct effects on human health. There may, however, be some indirect effects on human health from acid rain. Heavy metals such as copper, zi nc, cadmi um and mercury are liberated when soils and deposits are acidified. These contaminants, which are toxic and stored in the human body rather than released, can infiltrate ground water and enter into the human system. Additionally, they can enter the food chain by being absorbed by plants which in turn are consumed by grazing animals. Humans consume both plant and meat sources, and thus the accumulation of metals within the body increases (Park, 1987, p. 129). The full effects of the level of metals is yet unknown but diseases like osteomal acia have been linked to al uminium levels in drinking water. Well burn has also pointed out that deposits of al uminium in the brain are nor mally seen in cases of A Izhei mer's disease (Wel l burn, 1988, p. 128).

Highly water-soluble acidic vapours such as sulphur dioxide can penetrate the largest conductive airways of the lungs during periods of physical exercise. The result is that people wi th hyper-reactive airways, such as asthmatics, can experience wheezing and shortness of breath (Lippmann, 1992, pp. 307-8). The exposure of humans to chronic and cumulative doses of acidic aer osols can lead to chronic bronchitis (Li ppmann, 1992, p. 332). In J apan, skin and eye ir ritation has coincided with occasi ons when rainfall has been quite acidic (A nderson, 1986, p. 711). Further, acidification of ground water is becoming a growing concer $n$ in the developed world. The acidification of ground waters is being observed but the full impact is yet unknown. A cidification of ground water could have health implications due to the solubility of trace metals from the soil and bedrock and metal pipes in water distribution systems (Bricker and Rice, 1993, pp. 164-5). While there are grave difficulties in deter mining conclusively the role of acid deposition in the declining health of humans, the problem should not be under estimated and requires continued research.

\section{Outer space}

While health risk from space exploration would appear to be more properly placed in the real $m$ of science fiction, there are legitimate concer ns over space activities to warrant the careful conduct of space operations. One such risk is biological contamination (Qizhi, 1988, p. 119). Biological pollution can arise with the introduction of micro-organisms or bacteria into outer space, an occurrence known as forward contamination. A nother for $m$ of biological contamination is the introduction of extrater restrial microorganisms into the earth environment, a process known as back contami nati on ( $M$ atte, 1989, p. 425). Back contamination may also be 
Rajendra Ramlogan

Environment and human

health: a threat to all

Environmental Management and Health

8/ 2 [1997] 51-66 caused by the return to earth of micro-organisms that were initially carried from ear th into space and being exposed to conditions of outer space have mutated and retur ned in different or deadlier forms. Back contamination is not likely in view of the absence of any signs of life in outer space thus far. However, the dangers of retur ning an extrater restrial organism to earth or losing a bi ological agent in outer space, so affecting possible lifefor ms, should not be dismissed out of hand. The need, ther efore, exists for continued vigilance in this area (Robinson, 1992, pp. 326-30).

\section{Biotechnology}

A nother area of unknown health risk is related to the development of new microorganisms by means of bi otechnol ogy. Bi otechnology emerged as one of the controversial environmental issues of the 1980s, pitting environmentalists against the scientific community (J ukes, 1988). Biotechnol ogy now allows scientists to operate insi de the cells of living organisms and engage in acts of genetic engineering with the splicing together of DNA from different sources (Primrose, 1987, p. 8). This gene-spli cing ability, resulting in the recombining of pre-existing gene sequences, gave rise to the concept of recombinant DNA (J effries, 1989, pp. 27-9). There are many uses of bi otechnology that redound to man. However, while the health risks associated with bi otechnology are not yet identifiable, there is cause for genuine concer $n$ with respect to both the deliberate and unintended rel ease of new micro-organisms into the bi osphere. History has shown that some of the worst environmental disasters stemmed from the introduction of species from one environment to another. There is the need, therefore, for great caution in preventing the acci dental release of genetically engi neered micro-organisms into the atmosphere or their premature deliberate release. Additionally, in a more interdependent global village, a bi otechnologi cal disaster may have consequences beyond national boundaries.

Environmental degradation and human health: indirect consequences

\section{Wetlands}

Not only does environmental degradation directly affect human health, but there may be indirect consequences as well. An example of this phenomenon can be found in the case of wetlands. Wetl ands have always played an important role in human society starting from the great civilizations that thrived on the floodplains of the Nile, Tigris and
Euphrates rivers (Hook, 1993, p. 2157). Today they continue to play their part although under greater si ege from anthropogenic factors. Wetlands are important for their role in perfor ming certain chemical functions with respect to the decontamination of water. Wetlands trap water and filter out poll utants, especially nitrogen and phosphor us which are by-products of the explosion in the use of fertilizers (Holmstrom, 1995, p. 50). The removal of nitrogen and phosphorus helps in reducing the eutrophication process that adversely affects both freshwater and marine ecosystems (J acks et al., 1994, p. 358). Additionally, toxic residues such as heavy metals, pesticides and herbicides are al so removed by wetlands from water by ion exchange and absor ption in the organic and clay sediments. It has been estimated that the effectiveness and efficiency of the removal of toxic residues can vary between 20 to 100 per cent depending on the chemical profile of the toxic residue itself, the loading rate and the type of wetland (Hook, 1993, p. 2160). Finally, wetlands are very efficient in their ability to process human and animal waste material. In Wisconsin, for example, 86.2 per cent of the colifor $m$ bacteria present in domestic sewage is removed by the Brillion marsh (Williams, 1993, p. 22).

\section{Biological diversity}

Biological diversity is another area where environmental degradati on can indirectly impact on human health. One of the major benefits of biological diversity is its role in furnishing man with medical products. The dependence on nature to fur nish the cure for many human ailments is well documented. From penicillin to quinine, natural products have been used for the provision of life-saving medicines (McM ichael, 1993, pp. 243-5).

Between the period 1959-1973 over 25 per cent of all prescription drugs were plant-based (World Conservation Monitoring Centre 1992, p. 434). The WHO has claimed that worldwide, three-quarters of primary healthcare needs are met by traditional medicines with the figure rising to about 90 per cent in the devel oping world (M cM ichael, 1993, p. 244). In 1988, it was estimated that there were approximately 119 chemical substances extracted from around 90 species of higher plants that were being used in medicines throughout the world (Farnsworth, 1988, p. 83). As proof of the value of medicinal value of plants, the great battle against cancer has moved to the tropical forests where plant substances are showing positive signs in the fight against cancer cells (M cM ichael, 1993, p. 246). Not only plants, but also animals are proving useful in the devel opment of medical products. The frog population, though greatly 
Rajendra Ramlogan

Environment and human

health: a threat to all

Environmental Management and Health

8/ 2 [1997] 51-66 reduced, contains several chemicals that are quite promising in the development of human medi cines (McM ichael, 1993, p. 247). Indeed, it is fair to say that nature through its biological diversity has presented man with an extensively stocked pharmacy to repair broken bodies and minds. Destroying the world's biological diversity without fully understanding the properties of species lost can prove extremely deleteri ous to the sustaining or improvement of human exi stence throughout the world.

\section{Indigenous people}

The plight of indigenous people is increasingly being perceived as part of the environmental struggle, and the deci mation of these people and their culture and traditions may indirectly affect human health. The need is now stronger than ever to attempt to protect the cultures, languages and way of life of indigenous peoples. The M assachusetts I nstitute of Technology has estimated that 3,000 of the world's 6,000 languages are doomed because they are not spoken by children. These languages hold the key for understanding many aspects of the envi ronment. It has been noted that only about 1,100 of Earth's 265,000 speci es of plants have been thor oughly studied and as many as 40,000 may prove beneficial to man (O'Connor, 1994, p. 203). Indigenous communiti es are repositories for the understanding of the medi cinal or nutritional virtues of many living species, yet unknown to non-indigenous communities.

Flowing from the tremendous knowledge of indigenous peoples and, in particular, knowledge of plants, is the growing recognition that part of the answer to man's heal th and well lbeing resides in indigenous communities. Many drugs that are now commonly used are the products of folk medicines. A large percentage of drugs in use today are derived from plants and in some instances obtained directly from native knowledge, as for example, quinine (Yano, 1993, pp. 449-50). Indeed, it has been estimated that 25 per cent of all drugs in the USA use active ingredients extracted from plants. In 1990 the sale of these plant derived drugs realized income of $\$ 15.5$ billion. Further, it has been estimated that medicines derived from plants used by indigenous people produced a worldwi de sales income of $\$ 43$ billion. Tragically, only about 0.0001 per cent of the sales income has returned to the people that provided the breakthrough. An example is the Vinca rosea, a plant that is used to manufacture an important drug for treatment of childhood leukaemia. This plant was used by natives of Madagascar, yet the commercialization of a native remedy has brought no financial rewards (Rubin and Fish, 1994, pp. 27-8).

One fascinating dimensi on to the value of indigenous people to moder $n$ medical advancements lies within the bodi es of indigenous people themsel ves. Some indigenous people have demonstrated an ability to avoid cer tain diseases to which humans are otherwi se vulnerable. One man from the Hagahai tribe in Papua New Guinea has remained heal thy despite being infected with one of the few vir uses which cause cancer in humans. The response to this discovery has been efforts by the USA gover nment to obtain a patent to the tribesman's DNA. This has led to criticism focusing on the "ethics of preserving the DNA of endangered groups in laboratory jars rather than trying to save the people themselves, and of making millions of pounds from drugs derived from the genes of poor people without giving them a share in the benefits"(Lean and Wilkie, 1995, p. 1).

\section{Conclusion}

The battle to achi eve a satisfactory standard of adequate health in the global commons is a continuing one with perhaps greater implications for the developing world (Lear month, 1988). Table I provides a graphic illustration of the health profile of the developing world in contrast to the developed.

It is perhaps time that we retur ned to the precepts of the Greek goddess Hygeia with whom ancient Greeks entrusted their health.

$\overline{\text { Table I }}$

Health profile of the developing world in contrast with the developed world

\begin{tabular}{lccccccc}
\hline & $\begin{array}{c}\text { Crude } \\
\text { death } \\
\text { rate per of life } \\
\text { lost to } \\
\text { thousand } \\
\text { premature } \\
\text { death per } \\
\text { thousand }\end{array}$ & $\begin{array}{c}\text { Total } \\
\text { expenditure } \\
\text { on health as } \\
\text { \% of GDP }\end{array}$ & $\begin{array}{c}\text { Infant } \\
\text { mortality } \\
\text { rate per } \\
\text { thousand } \\
\text { (live births) }\end{array}$ & $\begin{array}{c}\text { Under-five } \\
\text { mortality } \\
\text { rate } \\
\text { (per 1,000 } \\
\text { live births) }\end{array}$ & $\begin{array}{c}\text { Underweight } \\
\text { children } \\
\text { (as \% of } \\
\text { children } \\
\text { under five) }\end{array}$ & $\begin{array}{c}\text { Life } \\
\text { expectancy } \\
\text { at birth }\end{array}$ \\
& 1993 & 1990 & 1990 & 1993 & 1993 & 1990 & 1993 \\
\hline Developed countries & 13 & 13 & 9.4 & 7 & 9 & - & 77 \\
Developing countries & 27 & 49 & 4.2 & 55 & 87 & 35 & 64
\end{tabular}

Source: UNDP, 1994, Tables 11 and 12; World Bank 1992, Tables 1, 26 and 27 
Rajendra Ramlogan

Environment and human

health: a threat to all

Environmental Management and Health

8/ 2 [1997] 51-66
Hygei a advocated good health through a sound personal environment, a philosophy that is becoming more relevant in the context of the rapid deterioration of the environment and the enor mity of the health consequences to humankind (Hall, 1990, pp. 7-19). This would appear to be the driving force behind the intent of Objective 6.40 of Agenda 21, where it was stated that "the overall objective is to minimise hazards and maintain the environment to a degree that human health and safety is not impaired or endangered and yet encourage development to proceed" (United Nations Conference on Environment and Development, 1992, pp. 49-50). It is clear, after reviewing the impact of different types of environmental problems on human health, that man is standing on the brink of a health cataclysm, with the threat moving beyond nati onal boundaries to encompass the entire global village.

\section{References}

Anderson, A . (1986), “Does J apan have acid rain?", Nature, Vol. 319, pp. 711.

Azizi, B.H.O. and Henry, R.L. (1990), “Effects of indoor air pollution on lung function of primary school children in Kuala Lumpur", Paediatric Pulmonol ogy, Vol. 9, pp. 24-9.

Biswas, A.K. (1989), “Environmental aspects of hazar dous waste management for developing countries: problems and prospects", in Maltezou, S.P., Biswas, A.K. and Sutton, H. (Eds), Hazardous WasteM anagement, Tycooly, New York, NY, pp. 261-71.

Blain, P.G. (1990), "A spects of pesticide toxicology", Adverse Drug Reactions \& AcutePoisoning Review, Vol. 9 No. 1, pp. 37-68.

Boleij, J.S.M., Ruigewaard, P., Hoek, F., Thairu, H., Walfula, E., Onyango, F. and Dekoning, $\mathrm{H}$. (1989), "Domestic air pollution from biomass burning in Kenya", Atmospheric Environment, Vol. 23No. 8, pp. 1677-81.

Bricker, O.P. and Rice, K.C. (1993), "Acid rain", Annual Review of Earth and Planetary Science, Vol. 21, pp. 151-74.

British Medical Association (1991), Hazardous Wasteand Human Health, Oxford University Press, New York, NY.

Carson, R. (1991), Silent Spring, Penguin Books, London.

Chen, B.H. (1990), "Indoor air pollution in developing countries", World Health Statistics Quarterly, Vol. 43, pp. 127-38.

Cortese, A.D. (1993), "Introduction: human health, risk and the environment", in Chivian, E. (Ed.), Critical Condition: Human Health and theEnvironment, MIT Press, Massachusetts, pp. 1-11.

Cunniff, P.F. (1977), Environmental Noise Pollution, J ohn Wiley \& Sons, Chichester.

Davidson, C.I. (1986), "Indoor and outdoor pollution in the Himalayas", Environmental Scienceand Technology, Vol. 20 No. 6, pp. 561-7.
Davies, B.E. (1987), “Lead: the environment and man: current issues", in Thornton, I. and Culbard, E. (Eds), Lead in theHomeEnvironment, Science Review Ltd, Northwood, pp. 3-13.

Diffey, B.L. (1992), “Stratospheric ozone depletion and the risk of non-melanoma skin cancer in a British population", Physics in Medicineand Biology, Vol. 37 No. 12, pp. 2267-79.

Donald, J.W. (1992), “The Bamako convention as a solution to the problem of hazar dous waste exports to lesser devel oped countries", Columbia J ournal of Environmental Law, Vol. 17, pp. 419-58.

Eichholz, G.G. (1977), Environmental Aspects of Nudear Power, Ann Arbor Science, Ann Arbor, MI.

Elsom, M. (1992), Atmospheric Pollution: A Global Problem, Blackwell, Oxford.

Farnsworth, N.R. (1988), "Screening plants for new medicines", in Wilson, O. (Ed.), Biodiversity, National A cademy Press, Washington, DC, pp. 83-97.

Faruqui, A.M. (1985), “Noise pollution: a neglected threat", I mpact of Science on Society, Vol. 35 No. 2/3, pp. 187-96.

Feachem, R.G. (1983), "I nfecti ons related to water and excreta: the health dimension of the decade", in Dangerfield, B.J . (Ed.), Water Supply and Sanitation in Devel oping Countries, The Institution of Water Engineers and Scientists, London, pp. 25-46.

Fishman, J . and Kalish, R. (1990), Global Alert: TheOzonePollution Crisis, Plenum Press, London.

Glasstone, S. and J ordan, W.H. (1980), Nuclear Power and its Environmental Effects, American Nuclear Society, Illinois.

Godlee, F. and Walker, A. (1992), "Health and the environment", British Medical J ournal, London.

Gold, D.R. (1992), “Indoor air pollution", Clinics in Chest Medicine, Vol. 13 No. 2, pp. 215-29.

Grei m, H. (1989), "Indoor air pollution: a review", Toxicological and Environmental Chemistry, Vol. 23, pp. 191-206.

Hall, R.H. (1990), Health and the Global Environment, Polity Press, Cambridge.

Henriksen, T., Dhalback, A ., Larsen, S.H.H. and Moan, J . (1990), "Ultraviolet-radiation and skin cancer: effect of an ozone layer depleti on", Photochemi stry and Photobiology, Vol. 51 No. 5, pp. 579-82.

Holmstrom, K. (1995), “Wetlands as nitrogen traps", Ambio, Vol. 24 No. 1, p. 50.

Hook, D.D. (1993), “Wetlands: history, current status and future", Environmental Toxicol ogy and Chemistry, Vol. 12, pp. 2157-66.

Ilyas, M. (1989), "The danger of ozone depletion in the tropics", Search, Vol. 20 No. 5, pp. 148-9.

J acks, G., J oelson, A . and Flei scher, S. (1994), "Nitrogen retention in forest wetlands", Ambio, Vol. 23No. 6, pp. 358-62.

J eevan, A . and Kripke, M.L. (1993), “Ozone depletion and the immune system", Lancet, Vol . 342, pp. 1159-60. 
Rajendra Ramlogan

Environment and human

health: a threat to all

Environmental Management and Health

8/ 2 [1997] 51-66
J effries, M. (1989), "Genetic engi neering", in Yanchinski, S. (Ed.), Biotechnol ogy: A Brave New World?, Lutterworth Press, Cambridge, pp. 23-31.

J ones, R.R. (1989), “Consequences for human health of stratospheric ozone depletion", in J ones, R.R. and Wigley, T. (Eds), OzoneDepletion: Health and Environmental Consequences, J ohn Wiley \& Sons, Chichester, pp. 207-27.

J ukes, T.H. (1988), “Hazards of bi otechnology: facts and fancy", J ournal of Chemical Technology and Biotechnology, Vol. 43, pp. 245-55.

Kerenyi, N.A., Pandula, E. and Feuer, G. (1990), "Why the inci dence of cancer is increasing: the role of 'light pollution'”, Medical Hypotheses, Vol. 33, pp. 75-8.

Kryter, K.D. (1985), TheEffects of N oiseon Man, A cademic Press, London.

Lambert, W.E. and Samet, J .M. (1994), “Combustion products: nitrogen dioxide, carbon monoxide and wood smoke", I mmunol ogy and Allergy Clinics of North America, Vol. $14 \mathrm{No}$. 3, pp. 607-20.

Lancet (1992), "Indoor air pollution and acute respiratory infections in children", Vol. 339, pp. 396-8.

Lean, G. and Wilkie, T. (1995), “US slaps patent on tribesman's DNA", I ndependent on Sunday, 19 November, p. 1.

Lear month, A . (1988), DiseaseE cology: An Introduction, Basil Blackwell, Oxford.

Lippmann, M. (1992), “Health effects of atmospheric acidity", in Radojevic, M. and Harrison, R.M. (Eds), Atmospheric Acidity: Sources, Consequences and Abatement, Elsevier Sciences, New York, NY, pp. 305-40.

Lippmann, M. and Schlesinger, R.B. (1979), Chemical Contamination in theHuman Environment, Oxford University Press, New York, NY.

Liu, Q., Sasco, A.J ., Riboli, E. and Meng, X.H. (1993), "Indoor air pollution and lung cancer in Guangzhou, People's Republic of China", American J ournal of Epidemiology, Vol. 137 No. 2, pp. 145-54.

Logan, B. (1991), "An assessment of the environment and economic implications of toxicwaste disposal in Sub-Saharan A frica", J ournal of World TradeLaw, Vol. 25, pp. 61-76.

Longstreth, J .A. (1990), "Human health", in Smith, J.B. and Tirpak, D.A. (Eds), ThePotential Effects of ClimateChangeon the United States, Hemisphere Publishing Corporation, New York, NY, pp. 525-56.

McConnell, R. and Hruska, A .J. (1993), "An epidemic of pesticide poisoning in Nicaragua: implications for prevention in developing countries", American J ournal of Public Health, Vol. 83 No. 11, pp. 1559-62.

McE wen, F.L. and Stephenson, G.R. (1979), TheUse and Significance of Pesticides in theEnvironment, J ohn Wiley \& Sons, Chichester.

McGranahan, G. and Songsore, J . (1994), “Wealth, health and the urban household: weighing environmental burdens in J akarta, Accra and Sao Paulo", Environment, Vol. 36, pp. 4-45.
McMichael, A.J . (1993), Planetary Overload: Global Environmental Changeand theHealth of theHuman Species, Cambridge University Press, Cambridge.

Madronich, S. and De Grujl, F.R. (1994), “Stratospheric ozone depletion between 1979 and 1992: implications for biologically active ultraviolet-B radiation and non-melanoma skin cancer inci dence", Photochemistry and Photobiology, Vol. 59 No. 5, pp. 541-6.

Matte, N.M. (1989), "Environmental implications and responsibilities in the use of outer space", Annals of Air and SpaceLaw, Vol. 14, pp. 419-47.

Milne, A. (1979), NoisePollution: I mpact and Counter measures, David \& Charles Ltd, Newton A bbot.

Morison, W.L. (1992), "Ultraviolet radiation and the immune system", in Marks, R. and Plewig, G. (Eds), TheEnvironmental Threat to the Skin, Martin Dunitz, London, pp. 47-50.

Nash, L. (1993), “Water quality and health", in Gleick, P.H. (Ed.), Water in Crisis: A Guideto theWorld's F resh Water Resources, Oxford University Press, New York, NY, pp. 25-39.

Neale, G. (1995), “Euro M Ps to hel p darken lightness for stars", TheSunday Tel egraph, 16 April, p. 4.

Nordberg, G.F. (1992a), "Introduction", in Nordberg, G.F., Herber, R.F.M . and Alessio, L. (Eds), Cadmium in theHuman Environment: Toxicity and Carcinogenicity, IA RC Scientific Publications, No 118, Lyon, pp. xi-xii.

Nordberg, G.F. (1992b), "A pplication of the 'critical effect' and 'critical concentration' concept to human risk assessment for cadmi um", in Nordberg, G.F., Herber, R.F.M . and Alessio, L. (Eds), Cadmium in theHuman Environment: Toxicity and Carcinogenicity, IA RC Scientific Publications, No 118, Lyon, pp. 3-14.

O'Connor, T.S. (1994), “'We are part of nature': indigenous peoples' rights as a basis for environmental protection in the A mazon Basin", Colorado J ournal of International Environmental Law and Policy, Vol. 5 No. 1, pp. 193-211.

Pandey, M.R. et al. (1989), “Indoor air pollution in devel oping countries and acute respi ratory infection in children", Lancet, Vol. 1, pp. 427-9.

Park, C.C. (1987), Acid Rain : Rhetoric or Reality?, Methuen, London.

Pentreath, R.J . (1980), Nuclear Power, Man and the Environment, Taylor \& Francis Ltd, London.

Petts, J . and Eduljee, G. (1994), Environmental I mpact Assessment for WasteT reatment and Disposal Facilities, J ohn Wiley \& Sons, Chichester.

Pimentel, D., A cquay, H., Biltonen, Rice, P. , Silva, M., Nelson, J ., Lipner, U., Giordano, S., Horowitz, A . and D'amore, M. (1992), “Environmental and economic costs of pesticide use", Bioscience, Vol. 42 No. 10, pp. 750-60.

Primrose, S.B. (1987), Modern Biotechnology, Blackwell Scientific, Oxford.

Qizhi, H. (1988), “Environmental impact of space activities and measures for inter national protection", J ournal of Space Law, Vol. 16 No. 2, pp. 117-27. 
Rajendra Ramlogan

Environment and human

health: a threat to all

Environmental Management and Health

8/ 2 [1997] 51-66
Rastogi, S.K. (1989), "Study of respiratory impai rment among pesticide sprayers in mango plantations", American J ournal of I ndustrial Medicine, Vol. 16, pp. 529-38.

Rei chard, E. (1990), Ground Water Contamination Risk Assessment : A Guideto Understanding and Managing Uncertainties, IA HS Publication, Wallingford.

Robinson, G.S. (1992), “Exobi ological contamination: the evolving law", Annals of Air and Space Law, Vol. 17 No. 1, pp. 325-67.

Rubin, S.M . and Fish, S.C. (1994), “Biodiversity prospecting: using innovative contractual provisions to foster ethnobotanical knowledge, technology and conservation", Colorado J ournal of International Environmental Law and Policy, Vol. 5 No. 1, pp. 23-58.

Ruyabhorn, P. and Phantumvanit, D. (1988), "Coastal and marine resources of Thailand: emerging issues facing an industrialising country", Ambio, Vol. 17 No. 3, pp. 229-32.

Schnei der, S. (1989), Global Warming: AreWe Entering the Greenhouse Country?, Lutterworth Press, Cambridge.

Secretariat of the United Nations Conference on Desertification (1977), Desertification: Its Causes and Consequences, Pergamon Press, Oxford.

Semu, E. and Singh, B.R. (1986), “Mercury pollution of effluent, air, and soil near a battery factory in Tanzania", Water, Air and Soil Pollution, Vol. 27, pp. 141-6.

Shapiro, S.A. (1993), "Rejoining the battle against noise pollution", I ssues in Scienceand Technology, Vol. 9 No. 3, pp. 73-9.

Smith, K.R. (1988), “Air pollution, assessing total exposure in developing countries", Environment, Vol. 30 No. 10, pp. 17-35.

Suite, W.H.E. (1991), "The export of hazardous waste to the Caribbean Basin regi ons", Toxicology \& Industrial Health, Vol. 7, pp. 221-7.

Taha, T.E. and Gray, R.H. (1993), “A gricultural pesticide exposure and perinatal mortality in Central Sudan", Bulletin of the World Health Organisation, Vol. 71 No. 3/4, pp. 317-21.

Tolba, M . and El-Kholy, O.A. (Eds) (1993), The World Environment 1972-1992: T wo Decades of Challenges, Chapman \& Hall, London.

United Nati ons Conference on Environment and Devel opment (1992), Agenda 21 : Programme for Action for SustainableDevel opment, United Nations, New York, NY.
United Nations Development Programme (UNDP) (1994), Human Devel opment Report 1994, Oxford University Press, Oxford.

United Nations Environmental Programme (UNEP) (1990), “Environmental effects of ozone depletion", J ournal of Photochemistry and Photobiology, Vol. 8, pp. 113-8.

United Nations Environment Programme (UNEP) (1993), Environmental Data Report 1993-94, 4th ed., Basil Blackwell, London.

Wellburn, A . (1988), Air Pollution and Acid Rain: TheBiological I mpact, Longman, Harlow.

White, R.R. (1993), North, South and theEnvironmental Crisis, University of Toronto Press, Toronto.

Wiesner, D. (1992), Your Health, Our World: The Impact of Environmental Degradation upon Human Wellbeing, Prism Press, Bridgeport.

Williams, M. (1993), “Understanding wetlands", in Williams, M. (Ed.), Wetlands: A Threatened Landscape, Blackwell, Oxford, pp. 1-41.

Wilson, C. (1993), Chemical Exposureand Human Health: A Referenceto 314Chemicals with a Guide to Symptoms and a Directory of Organisations, M CF arland \& Co., London.

Witt, V. (1982), "Water, health and development", International Water Resources Association, Water for Human Consumption: Man and his Environment, Tycooly, Dublin, pp. 301-11.

World Bank (1992), World Devel opment Report 1992: Devel opment and the Environment, Oxford University Press, New York, NY.

World Conservation Monitoring Centre (1992), Global Biodiversity: Status of theEarth's Living Resources, Chapman \& Hall, London.

Wu, Y.Q. (1989), “Occupational risk of decreased plasma cholinester ase among pesti ci de production workers in Tai wan", American J ournal of I ndustrial Medicine, Vol. 16, pp. 659-66.

Xu, Z.Y. (1989), “Smoking, air pollution, and the high rates of lung cancer in Shenyang, China", J ournal of theNational Cancer Institute, Vol. 81 No. 23, pp. 1800-6.

Yano, L.I. (1993), “Protection of the ethnobi ological knowledge of indigenous people", UCLA Law Review, Vol. 41, pp. 443-86.

Zhang, Z.F. (1988), "Indoor air pollution of coal fumes as a risk factor of stroke in Shanghai", American J ournal of Public Health, Vol. $78 \mathrm{No}$. 5, pp. 975-7. 